\title{
Valuation of ecosystem services in the organic carbon of the Pinus densiflora forest at Mt. Namsan, Seoul Metropolitan City
}

Eung-Pill Lee ${ }^{1}$, Soo-In Lee ${ }^{1,2}$, Heon-Mo Jeong ${ }^{3}$, Young-Sub Han', Seung-Yeon Lee', Jae-Hoon Park ${ }^{1,5}$, Rae-Ha Jang ${ }^{6}$, Youg-Sik Hong ${ }^{7}$, Young-Ho Jung ${ }^{1,8}$, Eui-Joo Kim, Sang-Hun Lee ${ }^{9}$ and Young-Han You ${ }^{1 *}$ (D)

\begin{abstract}
Background: Standing biomass, litter production, rate of litter decomposition, amount of litter on forest floor, and amount of soil organic carbon distribution were investigated from March 2016 to November 2018 in order to evaluate the ecosystem value through organic carbon distribution in the Pinus densiflora forest at Namsan, Seoul Metropolitan City.

Results: The amount of organic carbon in the Pinus densiflora forest was 261.09 ton $\mathrm{C} \mathrm{ha}^{-1}$ during the research

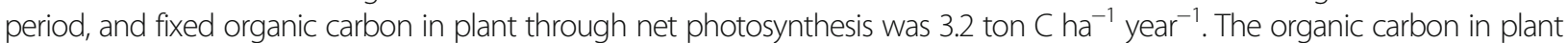
was 62.77 ton $\mathrm{C} \mathrm{ha}^{-1}(24.04 \%)$, in litter on the forest floor was $3.65{\text { ton } C \mathrm{Ch}^{-1}(1.40 \%) \text {, and in soil was } 194.67 \text { ton } \mathrm{C} \mathrm{ha}}^{-1}$ (74.56\%). The value of plant, litter on forest floor, and soil organic carbon distribution were each 6,277,000 won ha ${ }^{-1}, 365$, 000 won ha ${ }^{-1}$, and 19,467,000 won ha ${ }^{-1}$. The value per ton of fixed organic carbon in plant through net photosynthesis was 320,000 won ha $^{-1}$ year $^{-1}$ and the value of ecosystem services stored in carbon in the Namsan forest ecosystem was about 26.1 million won $\mathrm{ha}^{-1}$ for 3 years.

Conclusions: The results of this study suggest that the pine forests of Namsan rapidly decompose leaves due to the high atmospheric temperature and accumulate a large amount of organic carbon in the soil to provide climate control regulatory service function.
\end{abstract}

\section{Background}

The emission of artificial greenhouse gas has been increasing globally since the industrial era, and in particular, carbon dioxide emissions from the use of fossil fuels accounted for about $78 \%$ of total greenhouse gas emissions from 1970 to 2010 (IPCC 2014). In addition, Korea's greenhouse gas emission rate and amount have ranked first and eighth among OECD countries (Kim 2017). To cope with climate change, humans have been making efforts to reduce greenhouse gas by introducing the United Nations Framework Convention on Climate Change (UNFCCC) and the Kyoto Protocol. In addition, Korea has enacted the "Act on the Management and Improvement of Carbon Sinks" in 2013 to run a forest carbon offset system in order to maintain and enhance the function

\footnotetext{
* Correspondence: youeco21@kongju.ac.kr

${ }^{1}$ Department of Biological Sciences, Kongju National University, Kongju,

South Korea

Full list of author information is available at the end of the article
}

of forests, which are the sources of carbon absorption (Kim 2015).

Another alternative that can be implemented for greenhouse gas reduction is to increase carbon fixation in forests. Forest ecosystems are major sink of carbon and account for about two-thirds of the total photosynthesis on the Earth. Approximately $80 \%$ of the land ecosystem carbon and $40 \%$ of the soil carbon are stored in the form of aboveground and belowground biomass, dead tree, litter layer, and soil organic matter $(\mathrm{Hu}$ and Wang 2008; Dixon et al. 1994). In particular, organic carbon present as organic matter in forest ecosystems is related to the physical and chemical characteristics of soil, and the amount of organic carbon in soil is closely related to forest productivity and is important (Alban and Perala 1992). Forests provide public utility functions like biodiversity conservation, landscape preservation, and recreation services, along with its original function of wood production, and in particular, the importance of 
the public function of forests has been increasing due to the adoption of the Kyoto protocol in response to climate change (Korea forest service 2006).

Among the forest ecosystems, urban forest is one of the natural environments of the city, and although it has ecological characteristics different from those of healthy natural forests due to changes in urban environment (No 2015). And, urbanization has caused an ecosystem decline or degenerative transitions with alien species flourishing, mere vegetation structure, and declining species diversity (Oke and Rouse 1997; Roh et al. 2016). But, its value has been highlighted because it provides a function of ecosystem and city environment preservation and a place for citizens to enjoy leisure activities (No 2015). Moreover, about 65\% of the land in Korea is a forest, so by designating conservation areas by policy for valuable natural resources, we can strengthen the carbon control function of nature and contribute to climate change mitigation (Roh et al. 2016). In addition, as a result of analysis of carbon flow according to land use in various studies, urban residential area functions as a source of carbon dioxide, but natural park area functions as a fixing source of carbon dioxide (Amthor 1995; Barbour et al. 1999; Park et al. 2013). In this sense, Mt. Namsan, located in the center of Seoul, where urbanization and industrialization have progressed rapidly, is a representative urban forest that provides public utility to citizens of Seoul and carbon control function. A variety of benefits that humans receive from ecosystems are called ecosystem services, and the benefits range from basic supplies such as water and food to water quality and climate control (Costanza et al. 1997; MA 2005). Also, the Millennium Ecosystem Assessment divides ecosystem services into four categories according to their roles: provisioning service, regulating service, supporting service, and cultural service (MA 2005).

It is necessary to quantify the value provided by the ecosystem in order to evaluate the value of ecosystem and conserve and use it wisely (MA 2005). However, the evaluation of ecosystem services is very complicated and is scientifically in the initial stage. Although changes in the economic value of natural resources caused by climate change have been estimated, there is no research that has comprehended this at the level of ecosystem services (Brandera et al. 2012; Wattage 2011). In order to evaluate the ecological value of carbon cycle in Korea, researches have been done on natural forests, such as Quercus mongolica forest and Pinus densiflora forest in Mt. Worak, Quercus glauca forest, and Taxus cuspidata forest in Jeju Island (Won et al. 2015; Jang et al. 2017; Han et al. 2018), and they did not attempt to evaluate the ecological value of the carbon cycle for urban forests.
The purpose of this study is to quantify the distribution of organic carbon in Pinus densiflora forest, which is an exemplary urban forest in Seoul, and to estimate the social cost of natural resources caused by climate change at the level of ecosystem services.

\section{Materials and methods \\ Study site}

In Mt. Namsan, the highly natural northern slope Quercus mongolica forest and southern slope Pinus densiflora forest are distributed, and Pinus densiflora forest is recognized as an important forest in Seoul city after designation as an ecological landscape conservation area in December 2007 (Seoul Metropolitan Government 2009).

The permanent quadrate $(20 \times 20 \mathrm{~m})$ of the Pinus densiflora forest, which is the investigation branch of this study, is located on the southwest slope and has an elevation of about $170 \mathrm{~m}$ ( $37^{\circ} 32^{\prime} 94^{\prime \prime}$, E $\left.126^{\circ} 59^{\prime} 19^{\prime \prime}\right)$. It has a stand density (tree density) of 1400 tree ha ${ }^{-1}$, slope of $15 \sim 20^{\circ}$, and rock and gravel exposures of less than 5 and $3 \%$, respectively.

According to the weather data of the Seoul Metropolitan Meteorological Station (Jongno-gu, Seoul) located about $3 \mathrm{~km}$ from the investigation branch, the average temperature and the annual precipitation for the past 30 years (1988-2018) were $12.8^{\circ} \mathrm{C}$ and $1437.1 \mathrm{~mm}$, respectively, and during the investigation period (2016-2018), the average annual temperature was $13.2{ }^{\circ} \mathrm{C}$, while the annual precipitation was $1169.7 \mathrm{~mm}$ (Korea meteorological administration 2018).

\section{Standing biomass and net primary production}

A summation method is the best way to measure standing biomass, but it is difficult to measure standing biomass by woodcutting in the ecological landscape preservation area (Kang and Kwak 1998). Therefore, the standing biomass of the forest trees was calculated using that a specific relationship is established between the amount of growth of the organ constituting the plant and the amount of growth of the whole plant.

We measured the diameter at breast height $(D)$ and height $(H)$ of trees with a diameter longer than $2.5 \mathrm{~cm}$ in the perimeter and applied the measured values to an allometric equation to calculate the standing biomass.

The allometric equation used for the standing biomass measurement of Pinus densiflora tree layer in this study is as follows:

Allometric equation of Pinus densiflora forest (Kang and Kwak, 1998).

$\log \mathrm{Ws}=0.58482 \log \left(D^{2} H\right)-0.42417$

$\log \mathrm{Wb}=0.6234 \log \left(D^{2} H\right)-1.2321$

Wi (dry weight of each part); $s$, stem; $b$, branch

Leaves and reproductive organs were collected by litter trap each year and were used for standing biomass. 
Belowground biomass was calculated by applying $25 \%$ of the aboveground biomass (Johnson and Risser 1974).

For the measurement of shrub layer and herbaceous layer production, the shrub layer was collected from three $3 \times 3-\mathrm{m}^{2}$ quadrates, while the herbaceous layer was collected from three $1 \times 1 \mathrm{~m}^{2}$ aboveground in September every year from 2016 to 2018. The collected plant was transferred to the laboratory, dried for $72 \mathrm{~h}$ in a $60^{\circ} \mathrm{C}$ drying oven, and weighed and converted to standing biomass per unit area.

The amount of organic carbon of the plant for standing biomass and net primary production was estimated to be $45 \%$ of the dry weight (Houghton et al. 1983) while the annual organic carbon net primary production of each organ was calculated by subtracting this year's organic carbon $(\mathrm{C} 1)$ from the previous year's organic carbon $(\mathrm{C} 2)(\triangle \mathrm{C}=\mathrm{C} 2-\mathrm{C} 1)$.

\section{Annual litter production}

In order to quantify the amount of organic carbon recollected in the forest floor in a form of litter, 10 circular litter traps with a diameter of $60 \mathrm{~cm}$ were installed and litters trapped in the litter traps were collected seasonally (Yeochon Association for Ecological Research 2005). The collected litters were classified as leaves, branch, bark organ, reproductive organ, and others, and weighed after drying for $48 \mathrm{~h}$ in a $65^{\circ} \mathrm{C}$ drying oven. The amount of organic carbon was calculated by converting into litter production per unit area (hectare) based on the dry weight of the recollected litter per year and by applying organic carbon content (45\%).

\section{Litter layer of forest floor}

In order to quantify the amount of litter and organic carbon in the litter on the forest floor layer, four small $0.25 \times$ $0.25-\mathrm{m}$ squares were installed and collected by dividing them into L layer (litter layer) and F layer (fermentation layer). The collected litter was transferred to the laboratory and weighed after drying in a $65^{\circ} \mathrm{C}$ dryer until it became a constant weight. Based on the dry weight of the weighed clinical litter, the clinical litter per unit area (hectare) was calculated and the organic carbon content (45\%) was applied to calculate the organic carbon content.

\section{Decomposition of litter}

For the litter decomposition experiment, the litter was collected from the floor of the Pinus densiflora forest and dried for more than $48 \mathrm{~h}$ in a dryer at $80^{\circ} \mathrm{C}$. The litter bag was made using nylon net with a $2 \times 2-\mathrm{mm}$ mesh into a size of $25 \times 20 \mathrm{~cm}$; a 10 -g litter was placed in each bag. The litter bags were placed on the forest floor of each community and covered with litter.

Litter bags were collected at intervals of 1 month in the first 3 months after installation, and three bags were collected at every interval at 3-month intervals thereafter. The collected litter bags were dried for more than $48 \mathrm{~h}$ in a $65^{\circ} \mathrm{C}$ dryer after removing foreign matters on the outside and weighed.

For the residual weight of the litter, the residual amount from collection was expressed as a percentage (\%) of the initial weight, and the dissolution constant $(k)$ was calculated using Olson's equation $X_{t}=X 0_{e}^{-\mathrm{kt}}$, where $X 0$ is the weight before drying, $X_{t}$ is the weight after $t$ time, and $t$ is time (year) (Olson 1963).

\section{Soil collection and organic carbon analysis}

In order to measure the amount of organic carbon in the investigation area, soil was collected at intervals of $10 \mathrm{~cm}$ up to the depth of $50 \mathrm{~cm}$ and was transported to the laboratory after sealing in a plastic bag. Organic matter content was calculated by weighing $5 \mathrm{~g}$ of dried pellets in $105{ }^{\circ} \mathrm{C}$ dryer for over $48 \mathrm{~h}$, heating in $600{ }^{\circ} \mathrm{C}$ electric furnace for $4 \mathrm{~h}$, and then subtracting ash content from dry weight and dividing it by 1.724 for conversion (Black 1965). These data were used to calculate the accumulated amount of organic carbon of soil per unit area. The accumulation of organic carbon was calculated using the equation of Wang et al. (2002).

SOC (kilograms/square meter) = bulk density (tons/ cubic meter) $\times$ organic carbon content (grams/kilogram) $\times$ soil thickness $($ meter $) \times(1$-cobblestone ratio-rock ratio).

To measure the bulk density of the soil, soil was collected to a depth of $50 \mathrm{~cm}$ at a distance of $10 \mathrm{~cm}$ using a cylindrical soil sampler with a diameter of $5 \mathrm{~cm}$ and a length of $10 \mathrm{~cm}$. The collected soil was placed in a plastic bag and transported to a laboratory. The soil was dried and weighed in a $105^{\circ} \mathrm{C}$ dryer until it became a constant weight. The bulk density was then calculated by dividing this value by the volume. The stoniness content was measured by weighing particles that are $2 \mathrm{~mm}$ or bigger by $2 \mathrm{~mm}$ sieve and by calculating the ratio of the particle weight over $2 \mathrm{~mm}$ in total weight.

\section{Evaluation of ecological value through distribution of organic carbon}

Several studies currently quantify public utility functions for forests that provide diverse ecosystem services (Heywood et al. 1994). In particular, efforts are being made to quantify the value of forests' carbon sequestration and absorption-regulating functions (Prentice et al. 2001).

The European Union imposes a fine of $€ 100$ per ton of carbon dioxide, $\$ 6$ for Denmark, and $£ 30$ for the UK for emissions exceeding the greenhouse gas emission trading scheme (Ministry of Environment 2004). In Korea, Chapter 6, Article 33 (Fines) of the "Act on the Allocation and Trading of Greenhouse Gas Emissions Permits" has been enacted in 2013 and fines within the amount of KRW 100,000 per ton of carbon dioxide are imposed. 
Therefore, for the Pinus densiflora forest investigated in this study, the carbon dioxide value was applied by the law appropriate to the domestic situation and carried out calculation by applying KRW 100,000 per ton to the organic carbon investigated. And, prior to assessing the organic carbon value of each forest, it was assumed that the value of the currency obtained by conserving carbon without considering the initial investment cost of each forest was not changed to 100,000 won per year. Also, the costs invested for the protection and conservation of forests are ignored (Jung et al. 2011).

\section{Results and discussions}

\section{Standing biomass, amount of organic carbon, and net} primary production of plant

The standing biomass $\left(139.5 \pm 2.9\right.$ ton $\left.\mathrm{ha}^{-1}\right)$ and the organic carbon distribution $\left(62.77 \pm 1.31\right.$ ton $\left.\mathrm{C} \mathrm{ha}^{-1}\right)$ of the Pinus densiflora forest of the Mt. Namsan were higher than those of the Pinus densiflora forest in Mt. Worak (74.76 ton ha ${ }^{-1}$ and 37.38 ton $\mathrm{C} \mathrm{ha}^{-1}$ ) and the Pinus densiflora forest (85.87 ton ha ${ }^{-1}, 42.95$ ton $\mathrm{C} \mathrm{ha}^{-1}$ ) of Seosan, but they were lower than the measured values of Pinus densiflora forest in Uljin (310.2 ton ha ${ }^{-1}$, 139.6 ton $\mathrm{C} \mathrm{ha}^{-1}$ ) (Won 2015; Won et al. 2016; Jung 2015) (Fig. 1). The differences in the standing biomass of the same species are not climate factors such as height above sea level (Mt. Namsan, 170 m; Mt. Worak, 380 m; Seosan, $170 \mathrm{~m}$; Uljin, $580 \mathrm{~m}$ ), annual precipitation (Mt. Namsan, $1169.7 \mathrm{~mm}$; Mt. Worak, $1460.9 \mathrm{~mm}$; Seosan, $910.6 \mathrm{~mm}$; Uljin, $1166.6 \mathrm{~mm}$ ), and slope direction (Mt. Namsan, SW; Mt. Worak, SW; Seosan, S; Uljin, S) but differences in diameter at breast height (Mt. Namsan, $21.64 \mathrm{~cm}$; Mt. Worak, $16.63 \mathrm{~cm}$; Seosan, $16.8 \mathrm{~cm}$; Uljin,
$27 \mathrm{~cm}$ ) related in age (Won 2015; Won et al. 2016; Jung 2015).

Runyon et al. (1994) reported that the annual net primary production of coniferous forests in the temperate zone was 2.25 ton $C \mathrm{ha}^{-1}$ year $^{-1}$, but the annual net primary production of Pinus densiflora forests in different regions of Korea (Mt. Namsan, 3.2 ton $\mathrm{C} \mathrm{ha}^{-1}$ year $^{-1}$; Mt. Worak, 3.18 ton $\mathrm{C} \mathrm{ha}^{-1}$ year $^{-1}$; Seosan, 3.64 ton $\mathrm{C} \mathrm{ha}{ }^{-1}$ year $^{-1}$; Uljin, 7.56 ton $\mathrm{C} \mathrm{ha}{ }^{-1}$ year $^{-1}$ ) was found to be higher (Won 2015; Won et al. 2016; Jung 2015) (Fig. 2). Korea's $\mathrm{CO}_{2}$ emissions have increased by $2.3 \mathrm{ppm}$ annually over the past decade and have steadily exceeded the global average $\mathrm{CO}_{2}$ increase (2.2 ppm) (Ministry of Environment 2017). In addition, the annual average temperature rise $\left(0.5^{\circ} \mathrm{C} /\right.$ decade $)$ in Korea was higher than the average global average temperature rise $\left(0.12^{\circ} \mathrm{C} /\right.$ decade) (IPCC 2014). Runyon et al. (1994) reported that the average annual net primary production of temperate coniferous forests was 2.25 ton $\mathrm{C} \mathrm{ha}{ }^{-1}$ year $^{-1}$. This value is lower than that of the Pinus densiflora forest in Namsan Mountain. This result was considered to be from the fact that there were somewhat higher $\mathrm{CO}_{2}$ concentration, annual air temperature, and precipitation in this studied site, Seoul Metropolitan City, than other temperate forest ecosystem region in the world (National Institute of Environmental Research 2013).

\section{Organic carbon content of litter production}

The litter production (5.51 ton $\mathrm{ha}^{-1} \mathrm{year}^{-1}$ ) and the organic carbon content of litter production (2.48 ton $\mathrm{C} \mathrm{ha}^{-1}$ year $^{-1}$ ) of the of Pinus densiflora forest in Mt. Namsan were higher than those of Pinus densiflora forest in Mt. Worak

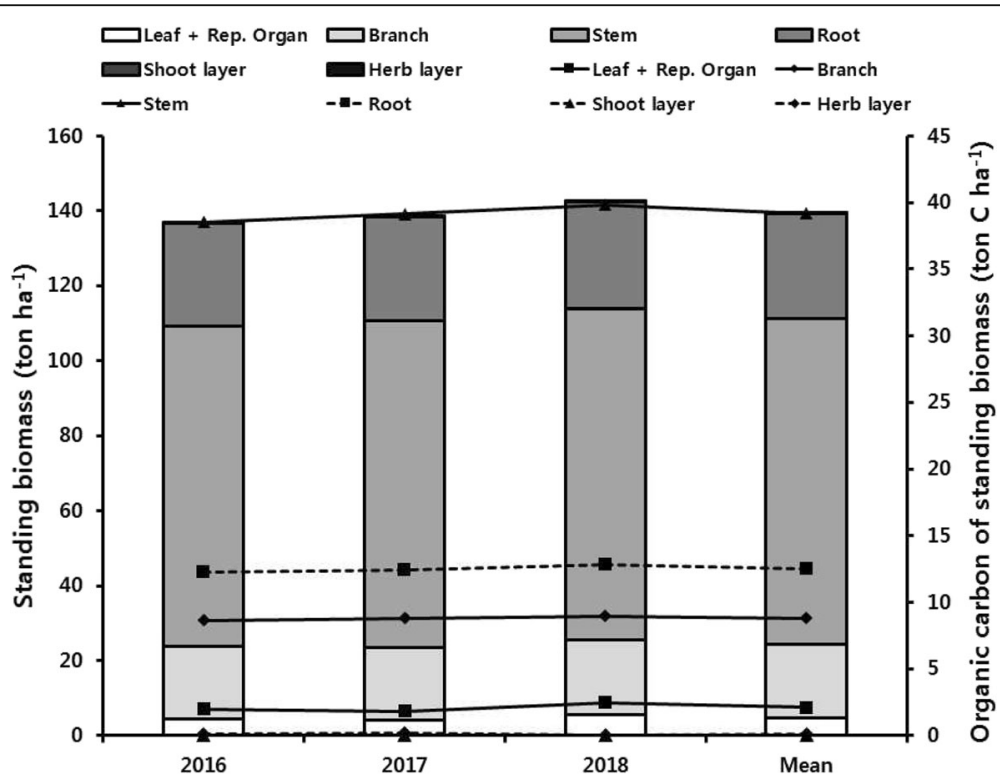

Fig. 1 Standing biomass (ton ha ${ }^{-1}$ ) and organic carbon of standing biomass of the Pinus densiflora forest in Mt. Namsan, Seoul Metropolitan City 


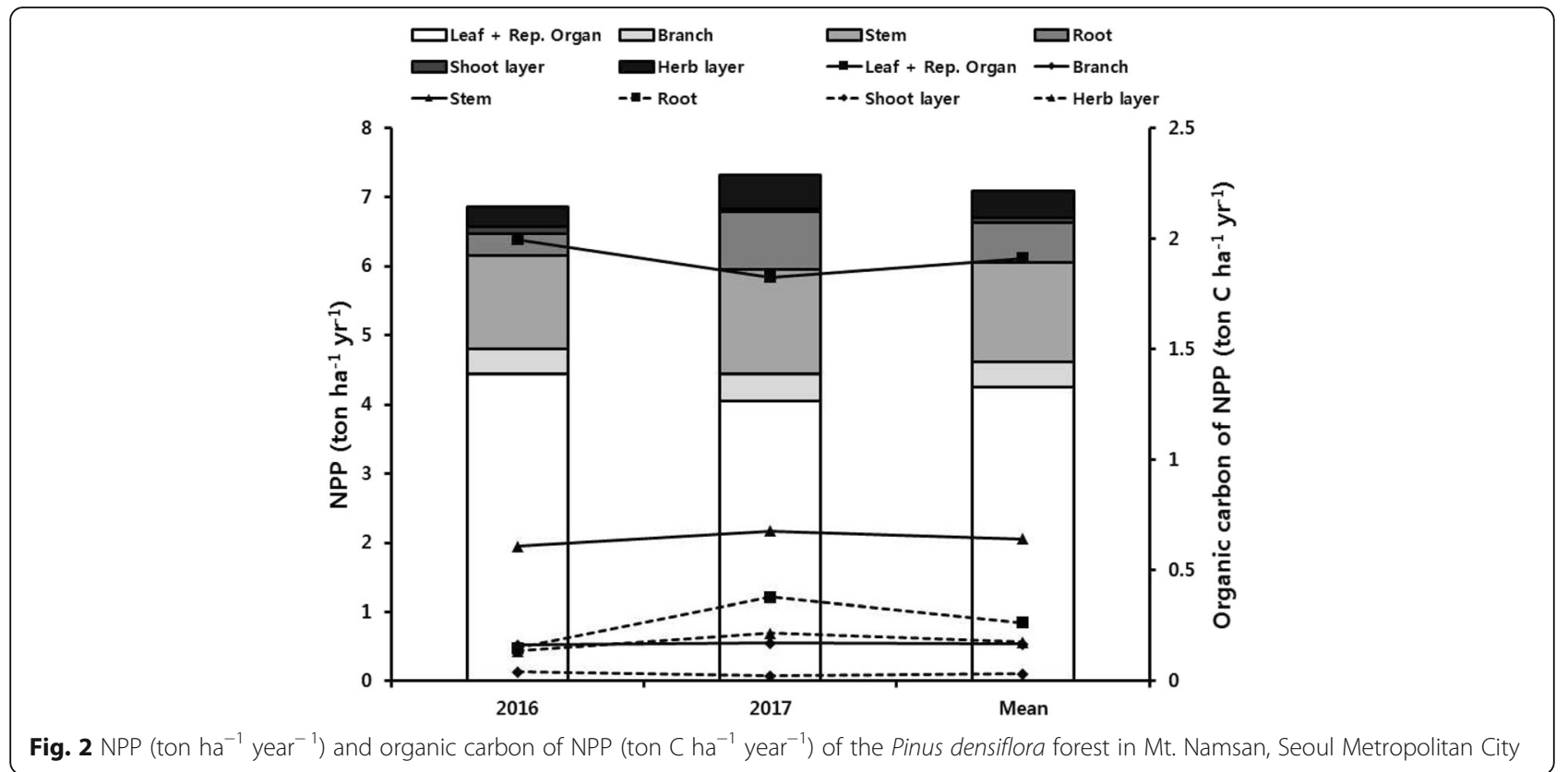

(3.81 ton $\mathrm{ha}^{-1}$ year $^{-1}, 1.91$ ton $\mathrm{C} \mathrm{ha}$ year $^{-1}$ ), Seosan (4.40 ton $\mathrm{ha}^{-1}$ year $^{-1}, 2.18$ ton $\mathrm{C} \mathrm{ha}{ }^{-1}$ year $^{-1}$ ), and Uljin (3.69 ton ha year $^{-1}, 1.66$ ton $C$ ha $^{-1}$ year $^{-1}$ ) (Won 2015; Won et al. 2016; Jung 2015) (Fig. 3).

In general, the litter production in the forest ecosystems is highly variable, depending on climate factors, elevations, and stand density (Sharma and Ambasht 1987; Hennessey et al. 1992). The elevation of Mt. Namsan $(170 \mathrm{~m})$ was lower than that of Mt. Worak $(380 \mathrm{~m})$ and Uljin $(580 \mathrm{~m})$, and it was the same as that of Seosan $(170 \mathrm{~m})$. The stand density (1400 tree ha ${ }^{-1}$ ) of Mt. Namsan was higher than that of Mt. Worak (1300 tree $\mathrm{ha}^{-1}$ ) and Uljin (838 tree $\mathrm{ha}^{-1}$ ) and lower than that of Seosan (1650 tree ha $\left.{ }^{-1}\right)$. As such, the elevation of Pinus densiflora forest of Mt. Namsan and Seosan were lower than that of the Pinus densiflora forest in Mt. Worak and Uljin, but due to the high stand density, the two regions (Mt. Namsan and Seosan) had more litter production than the two other regions (Mt. Worak and Uljin). In addition, the Pinus densiflora forests in Mt. Namsan and Seosan showed a difference in stand density even though they have the same elevation,

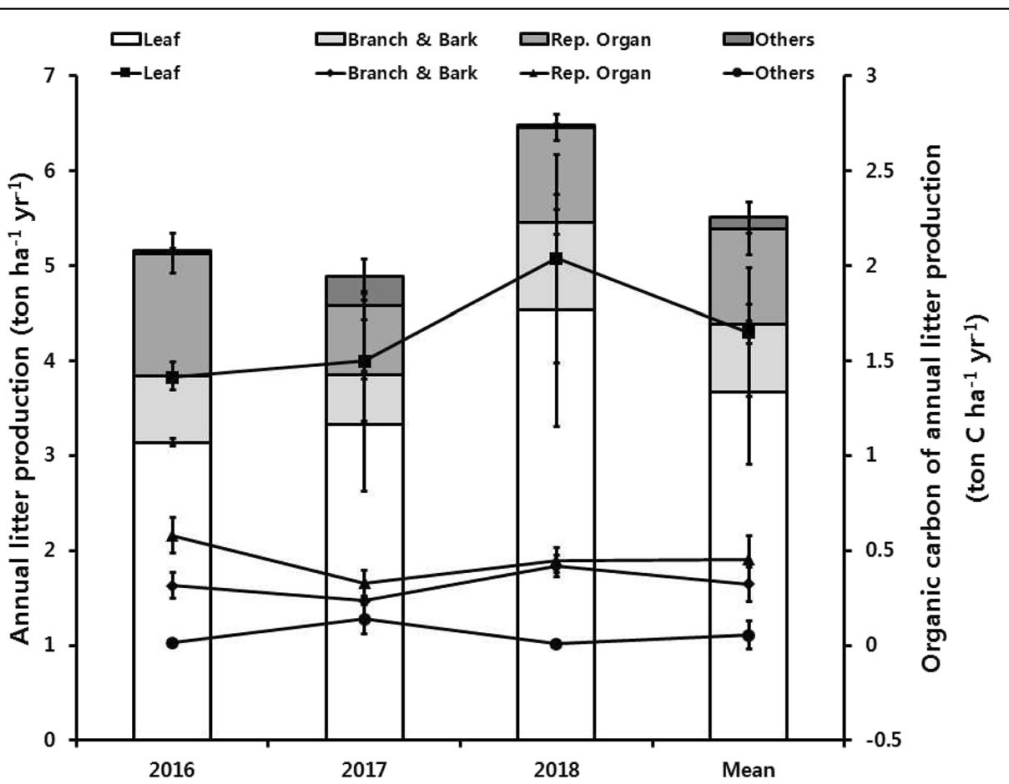

Fig. 3 Annual litter production (ton $\mathrm{ha}^{-1} \mathrm{yr}^{-1}$ ) and organic carbon of annual litter production (ton $\mathrm{C} \mathrm{ha} \mathrm{ar}^{-1} \mathrm{yr}^{-1}$ ) of the Pinus densiflora forest in Mt. Namsan, Seoul Metropolitan City 


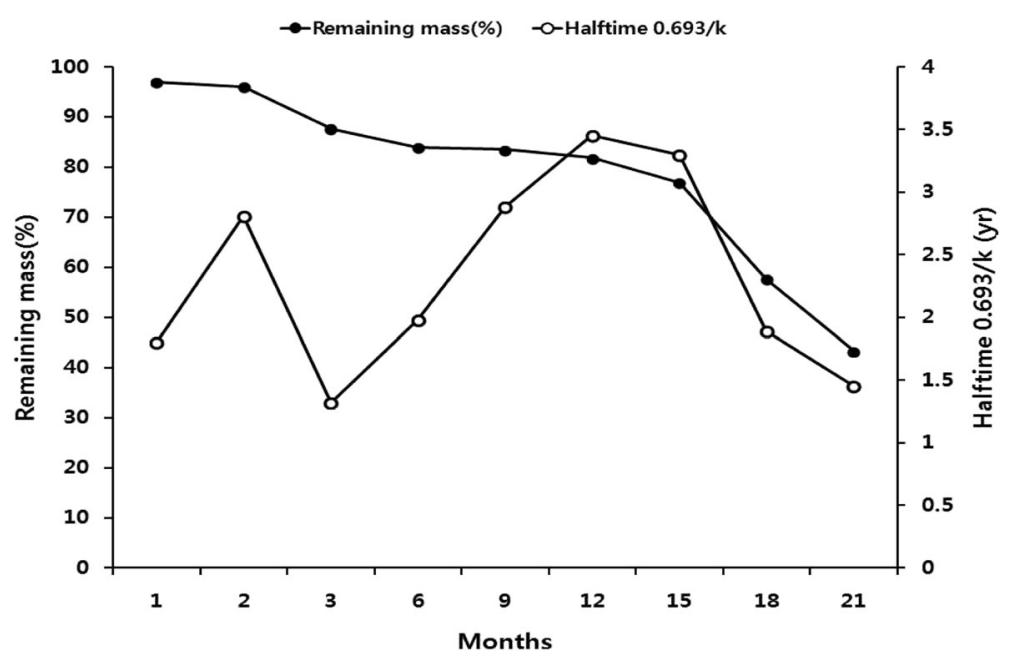

Fig. 4 Changes in remaining mass (percentage) and halftime 0.693/k (year) according to time (months) in litter on the forest floor of the $P$. densiflora forest in Mt. Namsan, Seoul Metropolitan City

and the litter production of Mt. Nansan Pinus densiflora forest was more than that of Seosan Pinus densiflora forest because the average annual temperature of Mt. Namsan $\left(13.2^{\circ} \mathrm{C}\right)$ was higher than that of Seosan $\left(12.4^{\circ} \mathrm{C}\right)$. An increase of temperature promotes the photosynthesis of plants (Kim 2012), and the increase of photosynthesis leads to more production of organic matters, such as leaves, branches, and reproductive organs, which explain the higher litter production of Mt. Namsan Pinus densiflora forest compared to that of the Pinus densiflora forest in Seosan.
Rate of litter decomposition and organic carbon content of litter layer on the forest floor

The decomposition time of $50 \%$ of litter $(t 50)$ in Mt. Namsan Pinus densiflora forest was 1.45 years, and it was smaller than that of other tree species (Gongju Pinus densiflora forest (t50), 2.97 years; Mt. Worak Jeokseong-myeon Pinus densiflora forest (t50), 1.9 years; Mt. Worak Hansu-myeon Pinus densiflora forest $(t 50), 1.6$ years; Gongju Pinus thunbergii forest (t50), 2.97 years; Gongju Pinus rigida forest (t50), 2.25 years; Gongju Pinus koraiensis forest (t50), 1.97

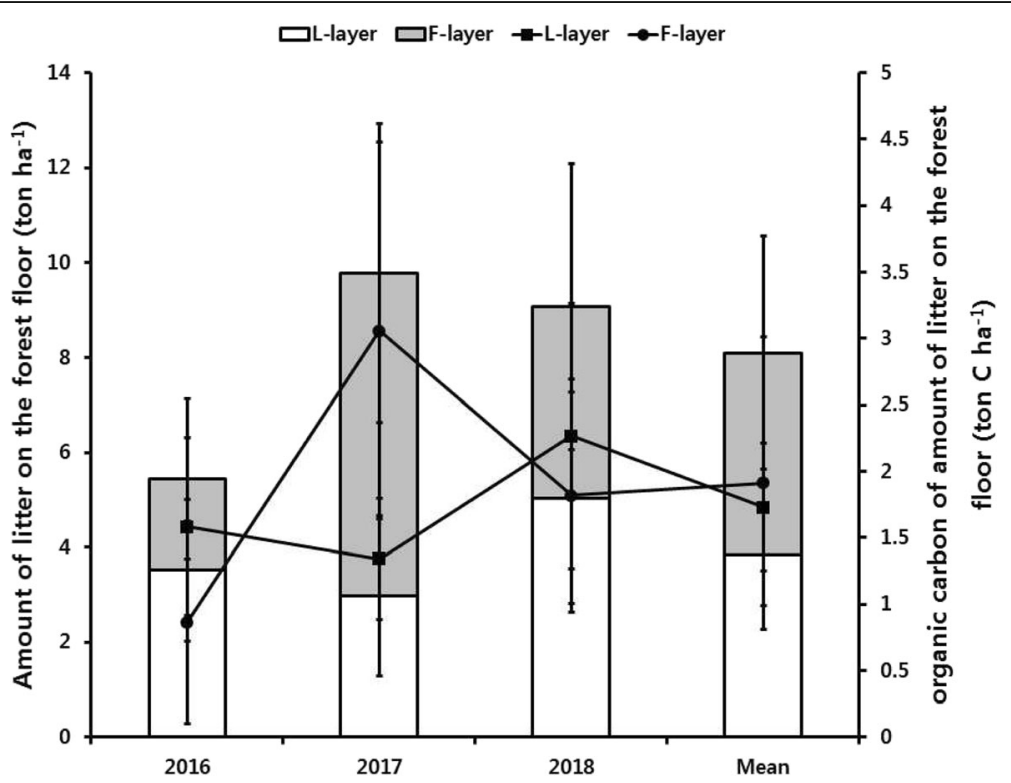

Fig. 5 Amount of litter on the forest floor (ton ha ${ }^{-1}$ ) and organic carbon of amount of litter on the forest floor (ton $\mathrm{C}$ ha ${ }^{-1}$ ) of Pinus densiflora forest in Mt. Namsan, Seoul Metropolitan City 


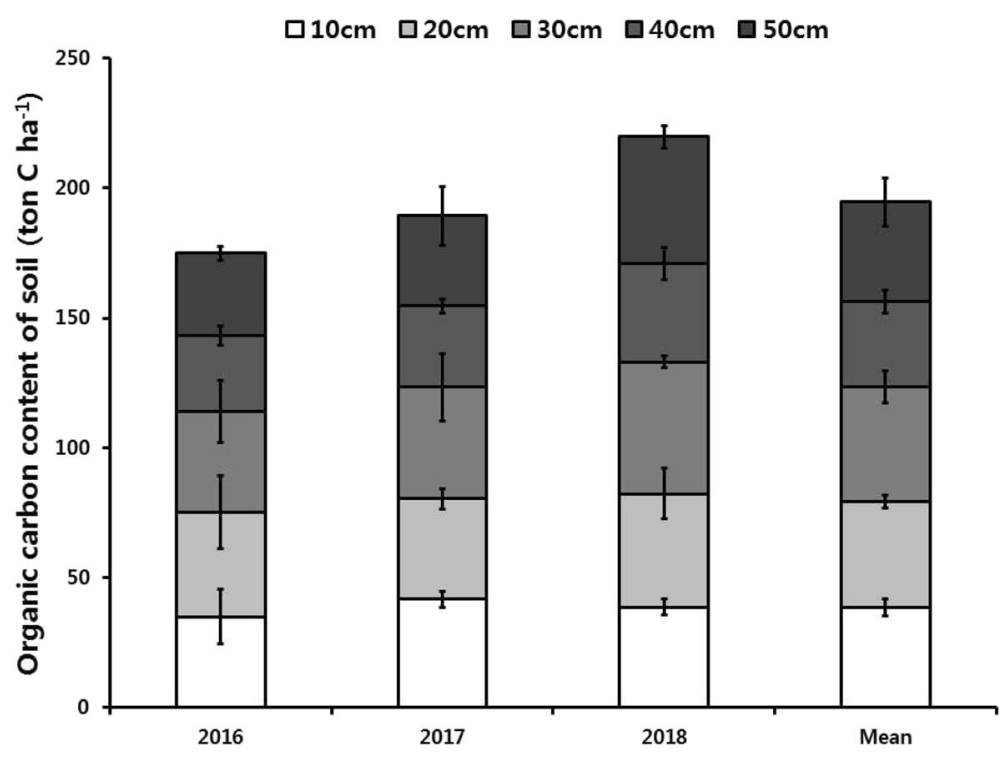

Fig. 6 Organic carbon content of soil (ton $\mathrm{C} \mathrm{ha}^{-1}$ ) along the soil depth of the Pinus densiflora forest in Mt. Namsan, Seoul Metropolitan City

years) (Lee 2017; Jo 2017; Sin and H. 2013) (Fig. 4). In general, the rate of litter decomposition varies greatly depending on precipitation, temperature, elevation, and orientation (Kim 1995). Mt. Namsan's precipitation $(1169.7 \mathrm{~mm})$ was higher than Mt. Hotae's $(887.9 \mathrm{~mm}$, average value of Gongju meteorological station over 3 years (2014-2016)), but it was lower than Mt. Worak's (1309.6 mm, average value of Jecheon meteorological station over 3 years (20102012)); the temperature of Mt. Namsan $\left(13.2^{\circ} \mathrm{C}\right)$ was also higher than that of Mt. Hotae $\left(13.0^{\circ} \mathrm{C}\right.$, average value of Gongju meteorological station over 3 years
(2010-2012)) and Mt. Worak $\left(8.5^{\circ} \mathrm{C}\right.$, average value of Jecheon meteorological station over 3 years (20102012)). Moreover, Mt. Namsan's elevation (170 m) was higher than Gongju's (124 m), but lower than Mt. Worak's (614 m), and Mt. Namsan's orientation (SW) was the same as Mt. Worak' (SW), while it was different from Gongju (NE) (Lee 2017; Jo 2017; Sin and H. 2013). These results show that the litter decomposition rate of the Mt. Namsan Pinus densiflora forest was faster compared to other tree species in areas far from the city because its temperature was higher than other regions.

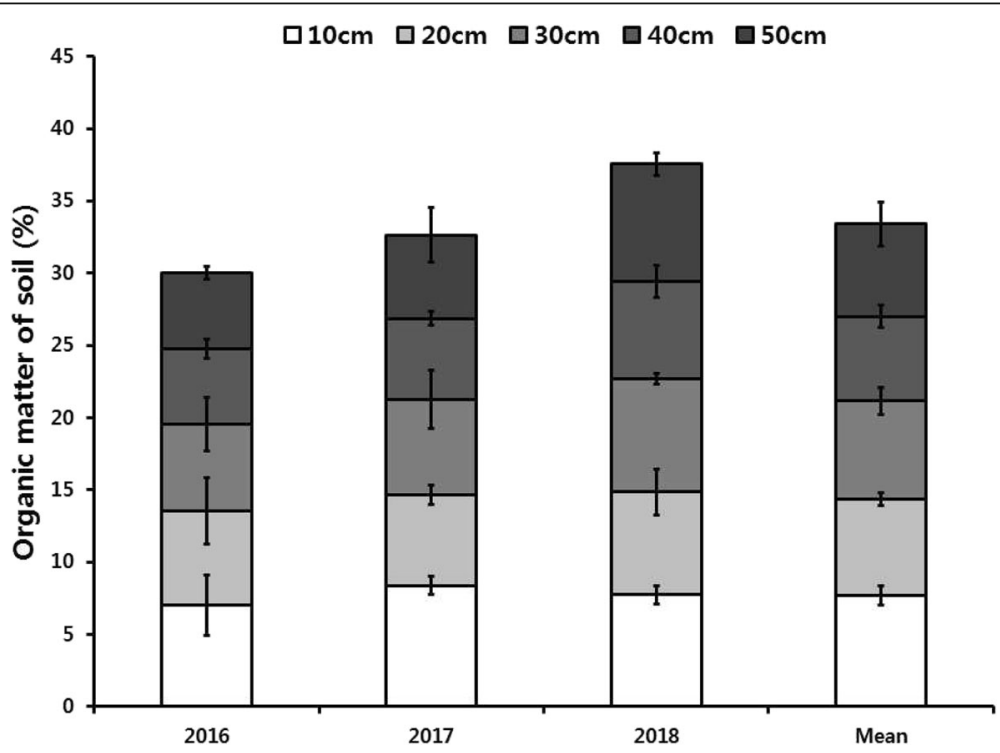

Fig. 7 Organic matter of soil (percentage) along the soil depth of the Pinus densiflora forest in Mt. Namsan, Seoul Metropolitan City 
Also, Mt. Namsan Pinus densiflora forest's amount of litter on the forest floor $\left(8.10\right.$ ton $\left.\mathrm{ha}^{-1}\right)$ and organic carbon content of the litter on the forest floor (3.65 ton $\mathrm{C} \mathrm{ha}^{-1}$ ) were less than Mt. Worak Pinus densiflora forest (13.92 ton ha ${ }^{-1}, 5.57$ ton $\left.\mathrm{C} \mathrm{ha}^{-1}\right)$, Seosan region's Pinus densiflora forest $\left(13.38\right.$ ton $\mathrm{ha}^{-1}$, 6.02 ton $\mathrm{C} \mathrm{ha}{ }^{-1}$ ), and Uljin Pinus densiflora forest (20.04 ton ha ${ }^{-1}, 9.02$ ton $\mathrm{C} \mathrm{ha}^{-1}$ ) (Won 2015; Won et al. 2016; Jung 2015) (Fig. 5). Mt. Namsan's precipitation $(1169.7 \mathrm{~mm})$ was greater than Pinus densiflora forests in Uljin $(1135.2 \mathrm{~mm})$ and Seosan $(910.6 \mathrm{~mm})$, but it was smaller than Mt. Worak Pinus densiflora forest (1460.9 $\mathrm{mm})$. Moreover, the elevation $(170 \mathrm{~m})$ of the Mt. Namsan Pinus densiflora forest was smaller than that of Uljin $(580 \mathrm{~m})$ and Mt. Worak's $(380 \mathrm{~m})$ Pinus densiflora forests but same as that of the Pinus densiflora forest $(170 \mathrm{~m})$ in Seosan. Yet, Mt. Namsan's average annual temperature $\left(13.2^{\circ} \mathrm{C}\right)$ was higher than that of the Pinus densiflora forests in Uljin $\left(12.6^{\circ} \mathrm{C}\right)$, Seosan $\left(12.4^{\circ} \mathrm{C}\right)$, and Mt. Worak $\left(10^{\circ} \mathrm{C}\right)$ (Won et al. 2016; Jung 2015). The difference in the amount of litter on the forest floor between the same tree species is possibly due to the difference in the rate of litter decomposition caused by temperature difference as the rate of litter decomposition is more affected by temperature than other climate factors (elevation, precipitation, orientation) regardless of the tree species and region.

\section{Accumulated organic carbon in soil}

The accumulated organic carbon in soil of Mt. Namsan Pinus densiflora forest (194.67 ton $\mathrm{C} \mathrm{ha}^{-1}$ ) was greater than that of the Mt. Worak Pinus densiflora forest (58.49 ton $\mathrm{C} \mathrm{ha}^{-1}$ ), Seosan Pinus densiflora forest (59.72 ton $\mathrm{C} \mathrm{ha}{ }^{-1}$ ), and Gongju Pinus ligida forest

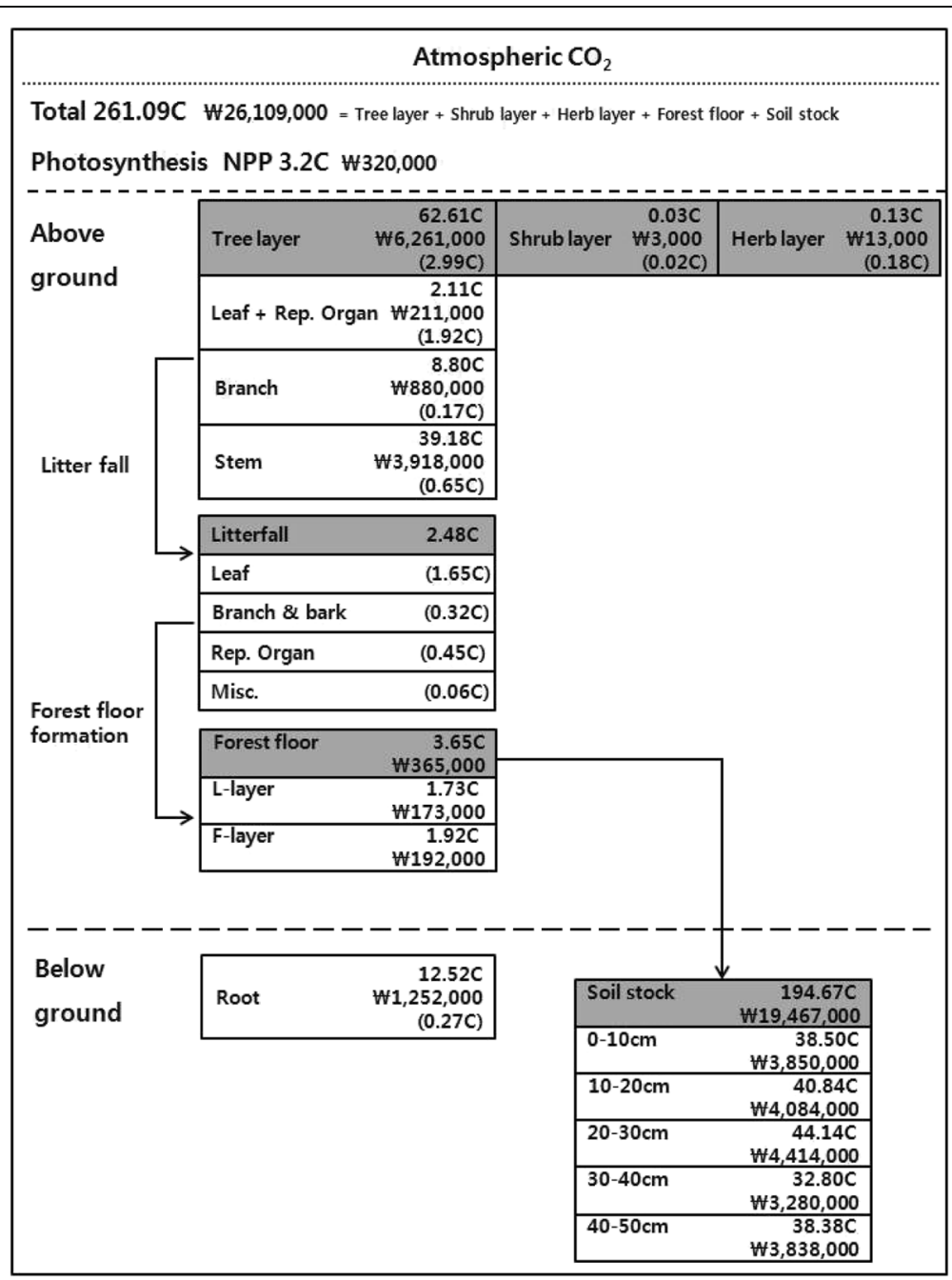

Fig. 8 Compartment model showing the valuation of ecosystem services (Won ha ${ }^{-1}$ ) through organic carbon distribution (ton $\mathrm{C} \mathrm{ha}{ }^{-1}$ ) of the Pinus densiflora forest for 3 years in Mt. Namsan, Seoul Metropolitan City. Gray box indicates standing carbon (ton $\mathrm{C} \mathrm{ha}^{-1}$ ), and an arrow indicates flux (ton C ha ${ }^{-1}$ year $^{-1}$ ). Parentheses indicate NPP (ton C ha ${ }^{-1}$ year $^{-1}$ ) 
(88.13 ton $\mathrm{C} \mathrm{ha}^{-1}$ ) when measured at the same depth $(50 \mathrm{~cm}$ ) of the soil (Won 2015; Won et al. 2016; Lee 2016) (Fig. 6). Also, the organic matter content of soil in Mt. Namsan Pinus densiflora forest $(6.68 \pm 0.68 \%)$ was higher than that of Mt. Worak Pinus densiflora forest $(3.16 \pm 0.06 \%)$, Seosan Pinus densiflora forest (3.05 \pm 0.56), and Gongju Pinus ligida forest $(3.24 \pm 0.19 \%)$ at the same depth of soil $(50 \mathrm{~cm})$ (Won 2015; Lee 2016) (Fig. 7). According to previous studies, the litter production of Mt. Namsan Pinus densiflora forest was higher than that of the Pinus densiflora forests in other areas, and the amount of litter on the forest floor was less than the Pinus densiflora forest's other areas. As a result, organic matters, such as litter, branches, and stems that came from aboveground, are decomposed more rapidly by microorganisms and organisms in the soil, leading to greater organic carbon and organic matter content of soil compared to other regions (Armson 1977; Chapman 1979).

\section{Evaluation of the ecological value of each member by organic carbon distribution in the Pinus densiflora forest}

The distribution of organic carbon in the Pinus densiflora forest was found to be 261.09 tons $\mathrm{C} \mathrm{ha}^{-1}$ on average. The average organic carbon distribution of each member was 62.61 ton $\mathrm{C} \mathrm{ha}^{-1}$ in the tree layer (23.98\%), 0.03 ton $\mathrm{C} \mathrm{ha}^{-1}$ in the shrub layer $(0.01 \%)$, and 0.13 ton $\mathrm{C} \mathrm{ha}^{-1}$ in the herbaceous layer (0.05\%), showing that 62.77 ton $\mathrm{C} \mathrm{ha}^{-1}$ (24.04\%) was accumulated in plants as a whole. The forest floor litter layer had an average of 3.65 ton $\mathrm{C} \mathrm{ha}{ }^{-1}$ of carbon $(1.40 \%)$ while the soil had an average of 194.67 ton $\mathrm{C} \mathrm{ha}^{-1}$ (74.56\%), indicating that the greatest amount of carbon was distributed in soil.

In addition, the amount of organic carbon fixed in plant through net photosynthesis was 3.2 ton $\mathrm{Cha}^{-1}$ year $^{-1}$ (Fig. 8). Similar to Mt. Namsan's Pinus densiflora forest, Mt. Worak and Seosan's Pinus densiflora forests also stored the most amount of organic carbon in the soil, but Uljin Pinus densiflora forest stored the most organic carbon in the plant. The litter on the forest floor of the Pinus densiflora forests in the Mt. Namsan, Mt. Worak, and Seosan areas (3.65 ton $\mathrm{C} \mathrm{ha}{ }^{-1}, 5.57$ ton $\mathrm{C} \mathrm{ha}{ }^{-1}$, 6.02 ton $\mathrm{C} \mathrm{ha}^{-1}$ ) were less than that on the Uljin Pinus densiflora forest (9.02 ton $\mathrm{C} \mathrm{ha}{ }^{-1}$ ), and this is possibly due to the difference in the amount of organic carbon in soil caused by the difference in the rate of litter decomposition (Won et al. 2016; Jung 2015).

The value per ton of organic carbon fixed in the plant through the net photosynthesis in the Pinus densiflora forest was about KRW $320,000 \mathrm{ha}^{-1}$, and the carbon storage value was about KRW 23.9 million ha ${ }^{-1}$ in 2016 and KRW 25.6 million $\mathrm{ha}^{-1}$ in 2017, steadily increasing to KRW 28.8 million $\mathrm{ha}^{-1}$ in 2018 (Fig. 8). When we estimated the value of organic carbon distribution by each member, the values of organic carbon distributed in the plant, the litter on the forest floor, and soil per ton were KRW 6,277,000 ha ${ }^{-1}, 365,000 \mathrm{ha}^{-1}$, and 19,467, $000 \mathrm{ha}^{-1}$, respectively, showing that the storage value of organic carbon in soil is the highest.

\section{Conclusions}

In this study, the Mt. Namsan Pinus densiflora forest's standing biomass, litter production, amount of litter on the forest floor, and distribution of organic carbon in the soil to evaluate the storage value of carbon by net primary production and each member were all assessed. The litter production of Mt. Namsan Pinus densiflora forest was higher than that of the Pinus densiflora forest in the countryside, but the amount of litter on the forest floor was lower while the amount of distribution in soil was very high. This is possibly due to the faster litter decomposition rate, owing to the higher temperature of big cities like Seoul compared to suburban areas.

The results of this study will be helpful to policy makers who are preparing policies for the conservation and management of coniferous forests in vulnerable ecosystems.

\section{Abbreviations}

OECD: Organization for Economic Cooperation and Development; IPCC: Intergovernmental Panel on Climate Change; UNFCCC: United Nations Framework Convention on Climate Change; MA: Millennium Ecosystem Assessment; L: Litter; F: Fermentation; SOC: Soil Organic Carbon; KRW: Korean Won; NPP: Net primary production

\section{Acknowledgements}

This work was supported by a grant from the National Institute of Ecology (NIE), funded by the Ministry of Environment (MOE) of the Republic of Korea (NIE-C-2018-21).

\section{Authors' contributions}

All authors conducted a survey together during the study period. LEP wrote the manuscript. YYH participated in the design of the study and examined the manuscript. All authors read and approved the final manuscript.

\section{Funding}

This work was supported by a grant from the National Institute of Ecology (NIE) and funded by the Ministry of Environment (MOE) of the Republic of Korea (NIE-C-2018-21).

\section{Availability of data and materials}

Not applicable.

Ethics approval and consent to participate

Not applicable.

\section{Consent for publication \\ Not applicable.}

\section{Competing interests}

The authors declare that they have no competing interests.

\section{Author details}

'Department of Biological Sciences, Kongju National University, Kongju, South Korea. ${ }^{2}$ Forest Plant Industry, Baekdudaegan National Arboreum, Bonghwa-gun, South Korea. ${ }^{3}$ Division of Ecosystem Service \& Research Planning, National Institute of Ecology, Seocheon-gun, South Korea. ${ }^{4}$ Division 
of Ecological Survey Research, National Institute of Ecology, Seocheon-gun, South Korea. ${ }^{5}$ K-water Convergence Institute, K-water, Daejeon, South Korea. ${ }^{6}$ National Institute of Ecology, Seocheon-gun, South Korea. ${ }^{7}$ Waterside Ecology Management Center, Korea Environmental Preservation Association, Seoul, South Korea. ${ }^{8}$ Seed Vault Department, Baekdudaegan National Arboreum, Bonghwa-gun, South Korea. ${ }^{9}$ Climate Change Research, National Institute of Ecology, Seocheon-gun, South Korea.

\section{Received: 21 March 2019 Accepted: 21 October 2019}

\section{Published online: 21 November 2019}

\section{References}

Alban DH, Perala DA. Carbon storage in Lake states aspen ecosystems. Can J For Res. 1992;22:1107-10.

Amthor JS. Terrestrial higher plant response to increasing atmospheric $\mathrm{CO}_{2}$ in relation to global carbon cycle. Glob Chang Biol. 1995;1:243-74.

Armson, K. A. (1977). Forest soils: properties and processes. University of Toronto Press. Canada. pp. 390.

Barbour MG, Burk JH, Pitts WD. Terrestrial plant ecology. Menlo Park, California: The Benjamin Cummings; 1999. p. 634.

Black CA. Methods of soil analysis, part 2. Madison, Wisconsin: American society of agronomy, Inc.; 1965. p. 1562-5.

Brandera LM, Wagtendonkb AJ, Hussainc SS, McVittiec A, Verburgb PH, de Groot RS, van der Ploegd S. Ecosystem service values for mangroves in Southeast Asia: a meta-analysis and value transfer application. Ecosystem Services. 2012:1:62-9.

Chapman SB. Some interrelationships between soil and root respiration in lowland calluna healthland in southern England. Ecology. 1979;67:1-20.

Costanza RD, Arge R, De groot RS, Farber S, Grasso M, Hannon B, Limburg K, Naeem S, O'Neill RV, Paruelo J, Raskin RG, Sutton P, Van den belt M. The value of world's ecosystem services and natural capital. Nature. 1997;387: 253-60.

Dixon RK, Brown S, Houghton RA, Solomon AM, Trxler MC, Wisniiewski J. Carbon pools and flux of global forest ecosystems. Science. 1994;263:185-90.

Han YS, Lee EP, Park JH, Lee SY, Lee SI, You YH. Organic carbon distribution and cycling in the Quercus glauca forest at Gotjawal wetland, Jeju Island, Korea. Journal of Ecology and Field Biology. 2018:42:8.

Hennessey TC, Dougherty PM, Cregg BM, Wittwer RF. Annual variation in needlefall of a loblolly pine stand in relation to climate and stand density. Forest Ecology Management. 1992;51:329-38.

Heywood DI, Price MF, Petch JR. Mountain regions and geographic information systems: an overview. In: Price MF, editor. Mountain environments and geographic information systems. London: Taylor \& Francis; 1994.

Houghton RA, Hobbie JE, Melillo JM, Moore B, Peterson BJ, Shaver GR, Woodwell GM. Changes in the carbon content of terrestrial biota and soils between 1860 and 1980: a net release of CO2 to the atmosphere. Ecol Monogr. 1983; 53:235-62

Hu H, Wang GG. Changes in forest biomass carbon storage in the South Carolina Piedmont between 1936 and 2005. For Ecol Manag. 2008;255(5-6):1400-8.

IPCC. (2014). Climate Change 2014: Synthesis Report. Contribution of Working Groups I, II and III to the Fifth Assessment Report of the Intergovernmental Panel on Climate Change [Core Writing Team, R.K. Pachauri and L.A. Meyer (eds.)]. IPCC, Geneva, Switzerland, 151.

Jang RH, Jeong HM, Lee EP, Cho KT, You YH. Budget and distribution of organic carbon in Taxus cuspidata forest in subalpine zone of Mt Halla. Journal of Ecology and Field Biology. 2017;41:4.

Jo, S U. (2017). Decay rate and nutrient dynamics during litter decomposition of Pinus rigida and Pinus koraiensis in Gongju. Master Dissertation. Kongju National University. Korea

Johnson FL, Risser PG. Biomass annual net primary production and dynamics of six mineral elements in a post oak-blackjack oak forest. Ecology. 1974;55: $1246-58$

Jung DJ, Kang KH, Heo J, Sohn MS, Kim HS. Valuation of biodiversity and ecosystem DDGSDGServices using National Forest inventory data. Korean Society of Environmental Impact Assessment. 2011;20(5):615-25.

Jung, S H. (2015). Carbon budget of Pinus densiffora forest in Uljin, Korea. Ph. D Dissertation. Chungnam National University. DaeJeon. Korea.

Kang SJ, Kwak AK. Comparisons of phytomass and productivity of watershed Forest by Allometry in South Han River. Journal of Korea Forestry Energy Research Society. 1998:17(1):8-12

Kim, J H. (1995). The stepping-stones for ecology in Korea. Seoul University Press.
Kim, J H. (2012). Global warming through the eyes of a biologist. Seoul University Press.

Kim NW. Public legal review on greenhouse gas emission rights. Korean Comparative Public Law Association. 2017;18(3):435-64.

Kim YH. Estimation of secondary emissions from forest carbon offset projects. Journal of Climate Change Research. 2015;6(4):257-65.

Korea forest service. (2006). A study on public benefit value and reduction plan of forests. Korea forest service.

Korea meteorological administration. (2018). Monthly report of automatic weather system data. Korea meteorological administration Press.

Lee, I H. (2017). Decay rate and nutrient dynamics during litter decomposition of Pinus densiflora and Pinus thunbergii in Gongju. Master Dissertation. Kongju National University. Korea.

Lee, Y S. (2016). Valuation of ecosystem services through organic carbon distribution and cycling in the Pinus rigida plantation of Mt. Hotae in Gongju. Master Dissertation. Kongju National University. Korea.

MA. 2005. Millennium ecosystem assessment: ecosystems and human well-being: synthesis. Island Press, Washington, D.C.

Ministry of environment. (2004). Study on implementation plan of domestic greenhouse gas emission trading system. Ministry of environment. pp. 185.

Ministry of Environment. (2017). 2017 White paper of environment. Ministry of Environment. pp. 363-380.

National Institue of Environmental Research. (2013). Executive summary for the third stage report (2010-2013) of KNLTER. National Institue of Environmental Research.

No, T H. (2015). The eco-adaptive urban Forest management methods of Namsan (Mt.) according to the urban environment change and Management in Seoul, Korea. Ph. D Dissertation. Seoul University. Seoul, Korea.

Oke, T R., Rouse, W R. (1997). The surface climates of Canada. McGill-Queen's university press. pp. 21-43.

Olson JS. Energy storage and the balance of producers and decomposers in ecological systems. Ecology. 1963;44:321-31.

Park MS, Joo SJ, Lee CS. Effects of urban park and residential area on the atmospheric $\mathrm{CO}_{2}$ concentration and flux in Seoul of Korea. Adv Atmos Sci. 2013;30:503-14.

Prentice, I C., Farquhar, G D., Fasham, M J R., Goulden, M L., Heimann, M., Jaramillo, V J., Kheshgi, H S., Le Quere, C., Scholes, R J., Wallace, D W R. (2001). The carbon cycle and atmospheric carbon dioxide. In: Climate Change 2001: The Scientific Basis. Contribution of Working Group I to the Third Assessment Report of the Intergovernmental Panel on Climate Change. In: Houghton, J.T. , et al. (eds.). Cambridge University Press, Cambridge, United Kingdom and New York, NY, USA. pp. 184-238.

Roh YH, Kim CK, Hong HJ. Time-series changes to ecosystem regulating Services in Jeju : focusing on estimating carbon sequestration and evaluating economic feasibility. Journal of Environmental Policy and Administration. 2016;24(2):29-44

Runyon J, Waring RH, Goward SN, Welles JM. Environmental limits on net primary production and light use efficiency across the Oregon transect. Ecol Appl. 1994:4:226-37.

Seoul Metropolitan Government. (2009). Study on establishment of Namsan ecological and landscape conservation area management plan -2nd year-. Seoul Metropolitan Government.

Sharma E, Ambasht RS. Litterfall, decomposition and nutrient releasein an age sequence of Alnus nepalensis plantation stands in the eastern Himalaya. Ecology. 1987:75:997-1010.

Sin, D, H. (2013). Estimation of net primary production, organic carbon mass and litter decomposition of plant community and its relation with environmental factors in Mt. Worak National Park. Master Dissertation. Kongju National University. Korea.

Wang G, Qian J, Cheng G, Lai Y. Soil organic carbon pool of grassland on the Qinghai-Tibetan plateau and its global implication. The Science of Total Environment. 2002;27:207-17.

Wattage, P. (2011). Valuation of ecosystem services in coastal ecosystems: Asian and European perspectives. Ecosystem Services Economics Working Paper Series.

Won, H Y. (2015). Valuation of ecosystem services through organic carbon distribution and cycling in the Quercus mongolica, Quercus variabilis and Pinus densiflora Forest at Mt. Worak National Park. Ph.D. Dissertation. Kongju National University. Korea.

Won HY, Kim DK, Han A, Lee YS, Mun HT. Distribution and absorption of organic carbon in Quercus mongolica and Pinus densiflora Forest at Mt. Gumgang in Seosan. Korean Journal of Environment and Ecology. 2016;30(2):243-52. 
Won HY, Lee YS, Mun HT. Valuation of ecosystem services through organic carbon distribution and cycling in the Pinus densiflora Forest in Mt. Worak National Park. Journal of Wetlands Research. 2015;17(4):332-8.

Yeochon Association for Ecological Research. (2005). Modern ecology experiment book. GyoMoon publisher.

\section{Publisher's Note}

Springer Nature remains neutral with regard to jurisdictional claims in published maps and institutional affiliations.

Ready to submit your research? Choose BMC and benefit from:

- fast, convenient online submission

- thorough peer review by experienced researchers in your field

- rapid publication on acceptance

- support for research data, including large and complex data types

- gold Open Access which fosters wider collaboration and increased citations

- maximum visibility for your research: over $100 \mathrm{M}$ website views per year

At $\mathrm{BMC}$, research is always in progress.

Learn more biomedcentral.com/submissions 